\title{
The illustrated Dioskourides codices and the transmission of images during antiquity*
}

\author{
JOSHUA J. THOMAS
}

\begin{abstract}
A parchment codex of the early sixth century A.D., now in Vienna, contains a remarkable series of nearly 400 full-page illustrations of individual botanical species. These illustrations accompany an alphabetical recension of a pharmacological treatise on the medicinal properties of plants written by Dioskourides of Anazarbos, a Greek author of the first century A.D. Both the date of the codex and the style of its botanical illustrations have precipitated suggestions that the latter were modelled somehow on classical archetypes. This article presents new observations in support of the classical archetypes theory, but questions the traditional view that these archetypes were transmitted by 'illustrated texts' or 'pattern books' executed in papyrus or parchment. What follows is a new hypothesis concerning the nature of the artistic intermediaries used by painters, mosaicists and sculptors during antiquity.
\end{abstract}

Key words: Dioskourides of Anazarbos; the Vienna Dioskourides; Anicia Juliana; illustrated manuscripts; pattern-books; artistic intermediaries; pinakes.

\section{INTRODUCTION}

Pedanios Dioskourides, a Greek pharmacologist from Anazarbos in Roman Cilicia,

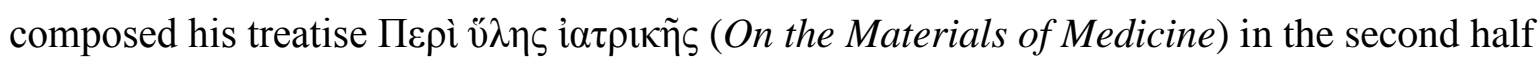
of the first century A.D. ${ }^{1}$ Today the text is more often known by its Latinised title, De

\footnotetext{
* I am very grateful to Bert Smith and Ine Jacobs for reading earlier drafts of this article, and to Mary Whitby for her helpful comments on the dedicatory epigram of the Vienna Dioskourides. I would also like to thank the Journal's anonymous reviewers for their useful comments and suggestions. Any remaining errors are mine alone.
} 
materia medica. This remarkable treatise enumerated the medicinal properties of more than 600 plants, as well as thirty-five animal products and ninety minerals. It was originally divided into five books, each of which was sub-divided into a long series of chapters, with each chapter treating a particular plant or medicinal product. The individual chapters were ordered according to a system of 'drug affinity': that is, according to the physiological effect(s) that they had - or were believed to have - on the human body. ${ }^{2}$

The arrangement of medical materials according to 'drug affinity' was undermined in the centuries following Dioskourides' death, when some versions of the treatise re-arranged the individual chapters into alphabetical order. ${ }^{3}$ A terminus ante quem for this re-arrangement is supplied by the Medical Collection written by Oribasius, the personal physician of the emperor Julian (361-363), in the second half of the fourth century. This text contained a condensed and alphabetised version of parts of Dioskourides' original treatise. ${ }^{4}$

A series of parchment codices containing lavishly illustrated versions of De materia medica were produced in late antique and Byzantine times. From a philological perspective, the most important is a ninth-century manuscript now in Paris containing a version of the original five-book treatise, which was used by Max Wellmann for establishing his authoritative version of Dioskourides' text. ${ }^{5}$ The subject of the present article, however, is the earliest and best-known illustrated Dioskourides codex: an early-sixth-century manuscript now in Vienna containing an alphabetical version of De materia medica accompanied by sumptuous full-page illustrations of the botanical species described in the text. These fullpage illustrations were painted on large parchment folios by skilled manuscript illuminators working in the usual secco technique. They were executed prior to the corresponding

\footnotetext{
${ }^{1}$ The bibliography on Dioskourides and his work is long. The most useful contributions include Wellmann 1903; Riddle 1971; id. 1984; id. 1985; Touwaide 1999; Cruse 2007; Scarborough 2011.

${ }^{2}$ First identified by Riddle 1985: 19-24, 94-131.

${ }^{3}$ Riddle 1985: 168-76.

${ }^{4}$ For Oribasius’ alphabetical rearrangement, see Scarborough 1984: 221-4; Riddle 1985: 17980 .
}

${ }^{5}$ Paris, Bibliothèque Nationale, MS gr. 2179. The critical edition is Wellmann 1906-1914. For criticism of Wellmann’s edition, see Riddle 1985: 213-14. 
chapters of text, judging by a folio on which a chapter of De materia medica was transcribed carefully around its associated illustration. ${ }^{6}$

Many of the botanical illustrations of the Vienna Dioskourides stand out by virtue of their astonishing naturalism, offering a stark contrast to more schematic, stylised representations of plants often found in late antique and early Byzantine art. It is because of this perceived dislocation between the style of the illustrations and the comparatively late date of the codex that previous studies have sometimes argued that the illustrations were modelled on classical archetypes. Most notably, Kurt Weitzmann (1904-1993) suggested that that the Vienna Dioskourides was a copy of an illustrated version of De materia medica produced when the text was first written in the second half of the first century A.D. ${ }^{7}$ This formed part of his overarching theory that late antique and Byzantine illustrated manuscripts were directly descended from (lost) illustrated books produced when the texts themselves were originally composed. ${ }^{8}$

Weitzmann's approach has since drawn criticism, particularly for how it obfuscates the significance of illustrated codices in their contemporary late antique and Byzantine contexts. ${ }^{9}$ His methodology is particularly difficult to uphold in the case of the Vienna codex, since there remains no consensus concerning whether Dioskourides’ De materia medica was originally illustrated. If anything, a majority of recent studies seem to incline to the view that the treatise was un-illustrated. ${ }^{10}$ Considerations in favour of this viewpoint include: that the text itself does not contain explicit references to illustrations; that the earliest papyrus

\footnotetext{
${ }^{6}$ This is the illustration labelled ' $\theta v \mu \varepsilon \lambda \alpha^{\prime} 1 \alpha$ ', probably a flax-leaved daphne (Daphne gnidium), on Folio $134 \mathrm{v}$.

${ }^{7}$ Weitzmann 1947: 135-6; id. 1959: 12. See also Horsfall 1983: 204: 'there is really no room for doubt that the magnificent illustrated manuscripts of this author [sc. Dioskourides] go back to an original on papyrus, in which not only text but pictures must have been the author's responsibility'.

${ }^{8}$ Fundamental are Weitzmann 1957; id. 1959; id. 1971; id. 1971.

${ }^{9}$ Recent reappraisals of Weitzmann’s methodology: Lowden 2002; Lazaris 2012; Touwaide 2013; Kalavrezou and Tomaselli 2017.

${ }^{10}$ So e.g. Orofino 1991; Cavallo 1992: 9-10; Blunt and Raphael 1994: 14; Collins 2000: 299301. For the opposite view, that the original treatise was indeed illustrated, see e.g. Riddle 1985: $176-80$.
} 
fragments of the treatise, dating to the second and third centuries A.D., are un-illustrated; ${ }^{11}$ and that Photius does not mention illustrations when discussing the original text.

This article seeks to uphold the view that the finest illustrations of the Vienna Dioskourides were descended from classical archetypes, while challenging Weitzmann’s influential assumption that these archetypes were earlier, unattested illustrated books. What will emerge is a new hypothesis concerning how detailed, polychrome images were transmitted and reproduced not only during Late Antiquity, but also during hellenistic and imperial times.

Any assessment of the illustrations of the Vienna Dioskourides requires a consideration of two further manuscripts containing alphabetical, illustrated versions of $D e$ materia medica: a late-sixth- or early-seventh-century codex now in Naples; and a tenthcentury codex now in New York. It has long been recognised that a significant number of botanical species are represented in a near-identical manner in all three codices, betraying a shared iconographic genealogy of some kind. This point is well-illustrated by the plant labelled $\kappa v ́ \alpha \mu \mathrm{s}$, representing the fava bean (Vicia fava L.), which appears on folio $189^{\mathrm{v}}$ of the Vienna codex, folio 86 of the Naples codex, and folio $75^{\mathrm{v}}$ of the New York codex (fig. 1). The species is depicted in a very similar manner in all three manuscripts, with a nearidentical arrangement of beans, branches and leaves around the central stem.

This shared artistic genealogy has traditionally been explained in one of two ways. According to the first view, the illustrations of the manuscripts in Naples and New York were copied directly from those of the earlier Vienna codex. This interpretation will be challenged in Section II of this article, where a series of differences between the three manuscripts will be highlighted that speak against the possibility that the Vienna codex served as an archetype for the two later codices. A second theory holds that the illustrations of all three manuscripts were copied from a now-lost authoritative codex, containing an alphabetical version of $D e$ materia medica accompanied by a comprehensive set of botanical illustrations. We shall see in Section III that this interpretation is also problematic, since a series of differences between the manuscripts in terms of their formatting, ordering and contents are difficult to reconcile with the notion of a lost authoritative codex. Rather, the most we can say is that all three codices depended on a pre-existing repertoire of detailed botanical illustrations that was

${ }^{11}$ For this pair of early, un-illustrated papyri containing extracts from De materia medica, see Windstedt 1907: 263-4; Bonner 1922; Riddle 1985: 178-9. 
already available when the Vienna Dioskourides was commissioned in the early sixth century.

The second half of this article will turn to examine this pre-existing repertoire of botanical illustrations in greater detail. In Section IV, it will be argued that the finest illustrations of the repertoire should be traced back to classical models that were first conceived in hellenistic or early imperial times. With this in mind, Section V will consider the question of how these 'classical' archetypes could have been preserved and transmitted prior to being reproduced in Late Antiquity. As we shall see, there are serious difficulties with the usual assumption that the repertoire was transmitted by 'illustrated texts' or 'pattern books' executed in papyrus or parchment. Rather, it is suggested here that the designers of the Vienna codex utilised a set of detailed representations of individual plants depicted on a much larger scale, possibly on whitened wooden boards. This new hypothesis has important implications for our understanding of ancient science, but also for our appreciation of how detailed artistic designs were transmitted and reproduced during antiquity. These implications are explored in Section VI.

\section{THE VIENNA ‘ARCHETYPE’ THEORY}

As we have noted, a large number of botanical species were depicted in a near-identical manner in the Vienna, Naples and New York manuscripts, precipitating the view that the illustrations of the latter pair were modelled directly on those of the former. Since this theory rests on the chronological precedence of the Vienna codex, it will be useful to introduce the manuscripts and the evidence for their dating, before evaluating the theory itself in more detail.

The Vienna Dioskourides (Österreichische Nationalbibliothek, Vienna, Codex Vindobonensis med. Gr. 1) 12

Dimensions: c. $37.0 \times 31.2 \mathrm{~cm}$

12 On the Vienna manuscript, see e.g. Diez 1903; Mantuani 1906; Gerstinger 1926: 19-21; id. 1970: 1-49; Buberl 1936: 114-36; id. 1937: 1-62; Stearn 1954; Blunt and Rafael 1994: 14-20; Stückelberger 1994: 78-83; Collins 2000: 39-50; Brubaker 2002: 189-209; Walther and Wolf 2005: 54-7; Lazaris 2017: 95-6. 
Script: $\quad$ Greek uncial majuscule

Date: $\quad$ The codex can be dated to c. 512 with precision, thanks to its famous dedicatory portrait (fol. $6^{v}$ ) of Anicia Juliana, a daughter of Flavius Anicius Olybrius, the emperor of the West for eight months prior to his death in $472 .{ }^{13} \mathrm{~A}$ barely-visible acrostic epigram surrounding the portrait records that the codex was a gift given to Anicia Juliana by the citizens of Honoratae, a district of Constantinople, in thanks for her construction of a 'temple of the Lord' in their part of the city. ${ }^{14}$ Further information is supplied by Theophanes Confessor, who records that Juliana dedicated a church of the Virgin Mary in Honoratae in $512,{ }^{15}$ hereby providing an approximate date for the production of the codex.

Provenance: Constantinople. It is possible that the codex was produced in an imperial scriptorium. ${ }^{16}$

Contents: $\quad$ (1) a series of prefatory illustrations and a decorative title page (fols. $1^{\mathrm{v}}-7^{\mathrm{v}}$ ), ${ }^{17}$

(2) an alphabetical index of plants listing 264 of the species discussed in the following version of Dioskourides’ text (fols. 8-10);

(3) an 'Alphabetical herbal recension’ of Dioskourides' De materia medica, accompanied by 382 illustrations of medicinal plants (fols. 10v-387);

(4) the Carmen de viribus herbarum, a poem concerning healing herbs, illustrated with a representation of a coral flanked by a marine deity or personification (fols. 388-392);

(5) Euteknios’ paraphrase of the Nikander of Kolophon's Theriaka, illustrated with paintings of poisonous creatures and the sources of their antidotes (fols. 393-437v); (6) Euteknios' paraphrase of the Nikander of Kolophon's Alexipharmaka with spaces for illustrations that were never filled (fols. 438-459v);

(7) an incomplete paraphrase of Oppian’s Halieutica, un-illustrated (fols. 460-473);

${ }^{13}$ Dedicatory portrait: Spatharakis 1976: 145-8; Kiilerich 2001; Nathan 2011. On Anicia Juliana herself, see Capizzi 1968; Jones, Martindale and Morris 1980: 635-6.

${ }^{14}$ Epigram: von Premerstein 1903: 110-13.

15 Theophanes, Chron. A.M. 6005

${ }^{16}$ For an imperial scriptorium in Constantinople during the reign of Constantius II (337-361), see Themistius, Or. 4.59d-61h, with commentary in Wilson 1967: 60-1; id. 1996: 50-1; Lemerle 1986: 57-9. For Byzantine book culture more broadly, see Lowden 2008; Waring 2010.

${ }^{17}$ For bold new interpretations of several of these prefatory illustrations, see J. C. Anderson 2009: 32-9. 
(8) a paraphrase of Dionysios of Philadelphia's Ornithiaka, a treatise on birds and bird-catching, illustrated with twenty three birds interspersed with the text and a further twenty four birds set within a gridded frame on a single folio (fols. 474-485v).

The Naples Dioskourides (Bibliotheca Nazionale, Naples, Cod. gr. 1) ${ }^{18}$

Dimensions: $\quad$ c. $28.7 \times 26.0 \mathrm{~cm}^{19}$

Script: $\quad$ Greek uncial majuscule

Date: $\quad$ Late sixth or early seventh century A.D. (palaeography)

Provenance: A series of graphic, codicological and artistic considerations suggest that the manuscript may have been produced in Italy, possibly in Ravenna. ${ }^{20}$

Contents: (1) an 'Alphabetical herbal recension’ of Dioskourides’ De materia medica, accompanied by 409 illustrations of medicinal plants (fols. 1-172). ${ }^{21}$

The New York Dioskourides (Pierpont Morgan Library, M 652) 22

Dimensions: $\quad 39.5$ x $29.0 \mathrm{~cm}$

Script: $\quad$ Greek miniscule bouletée

Date: $\quad$ Early to mid tenth century A.D. (palaeography).

Provenance: Constantinople. It has been suggested that the manuscript should be associated with the court of Constantine VII Porphyrogenitus (913-959). ${ }^{23}$

Contents: (1) a version of the 'Alphabetical Five Book recension’ of De materia medica (fols. $1^{\mathrm{v}}-305^{\mathrm{v}}$;

(2) a treatise on the helpful and harmful power of strong drugs, erroneously attributed to Dioskourides (fols. 306-319v);

${ }^{18}$ On the Naples manuscript, see e.g. Anichini 1956: 77-108; Bianchi Bandinelli 1959: 4851; Cavallo 1992; Lilla 1992; Orofino 1992; Bertelli 1992; Blunt and Rafael 1994: 21-3; Collins 2000: 51-9; Lazaris 2017: 96-8.

${ }^{19}$ Note, however, that the upper margin of the codex has been trimmed: see Lilla 1992: 58. ${ }^{20}$ So Bertelli 1992. For the alternate view that the manuscript was made in Constantinople, see Anichini 1956: 102.

${ }^{21}$ Originally there were 434 botanical illustrations, but eleven or twelve folios of the codex are now missing: so Lilla 1992: 60-8.

${ }^{22}$ On the New York manuscript, see e.g. van Buren 1973; Collins 2000: 59-69; Cronier 2012.

${ }^{23}$ So e.g. Weitzmann 1971: 139-9. 
(3) a treatise on poisons and their effects, erroneously attributed to Dioskourides $\left(319^{\mathrm{v}}-327^{\mathrm{v}}\right)$;

(4) a treatise on the cure of efficacious poisons, erroneously attributed to

Dioskourides (fols. 328-330v);

(5) an un-illustrated Mithridatic anecdote (fols. 331-333v);

(6) an anonymous poem on the powers of herbs that may be related to the Carmen de viribus herbarum of the Vienna codex, here un-illustrated (fols. 334-338);

(7) an illustrated version of Euteknios' paraphrase of Nikander's Theriaka (fols. 338$361)$;

(8) an illustrated version of Euteknios' paraphrase of Nikander's Alexipharmaka (fols. 361 ${ }^{\mathrm{v}}$-375);

(9) an incomplete, un-illustrated paraphrase of Oppian’s Halieutica (fols. 375-376 v).

In short, the early-sixth-century Vienna Dioskourides contains 382 botanical illustrations, the late-sixth- or early-seventh-century Naples Dioskourides contains 409 botanical illustrations, and the tenth-century New York Dioskourides contains 443 botanical illustrations. ${ }^{24}$

Of the 382 species illustrated in the Vienna Dioskourides and the 409 illustrated in the Naples Dioskourides, 350 are common to both manuscripts. In the majority of cases, the illustrations are sufficiently similar to suggest that they are 'genetically connected': that is, they share a sufficient number of intricate, closely-observed details to suggest that they are both versions of the same original design, even if they sometimes also exhibit stylistic and/or iconographic idiosyncrasies that speak against the possibility that one illustration was modelled directly on the other. ${ }^{25}$ A representative example is supplied by the plant labelled

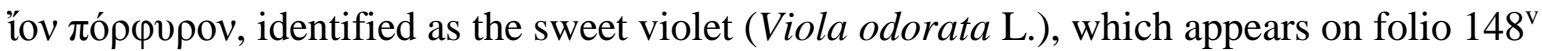
of the Vienna codex and folio 42 of the Naples codex. Here the shared heritage of the illustrations is underscored by the symmetrical arrangement of the two tallest flowers, and the presence of seven heart-shaped leaves emanating from the central stem (fig. 2).

\footnotetext{
${ }^{24}$ The typological analysis that follows here was much-aided by an online database cataloguing the botanical illustrations of the Vienna, Naples and New York manuscripts, which was produced to accompany a short article by the botanists Janick, Whipkey and Stolarcyzk (2013), and which can be browsed online at: https://hort.purdue.edu/newcrop/herbalimages/ (last accessed 12 April 2019). ${ }^{25}$ Observed, for instance, by Weitzmann 1959: 12-13; Orofino 1992: esp. 101-5; Collins 2000: 56; Janick and Stolarcyzk 2012: 9-17.
} 
But there are also instructive differences between the illustrations of the two codices. Most importantly, the Naples Dioskourides contains fifty-five botanical illustrations that are not found in the Vienna Dioskourides, only two of which can be accounted for by missing folios of the latter manuscript. ${ }^{26}$ It follows that fifty-three of the illustrations included in the late-sixth- or early-seventh-century Naples Dioskourides were not included in the early-sixthcentury Vienna Dioskourides. This observation is significant, since it precludes the possibility that the botanical illustrations of the Naples codex were modelled directly and exclusively on those of the Vienna codex, suggesting that the close iconographic correspondences between the two manuscripts need to be explained in another way. ${ }^{27}$ Further support for this conclusion is supplied by the nineteen or so botanical species that are accompanied by different illustrations in the two manuscripts, ${ }^{28}$ since the dependence of one codex upon the other can likewise be excluded in these cases. A good example is provided by

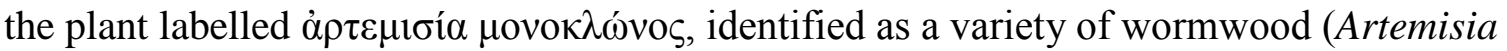
campestris L.), which appears on folio $20^{\mathrm{r}}$ of the Vienna manuscript and folio 3 of the Naples manuscript (fig. 3). The specimen depicted in the Vienna codex seems more developed than its counterpart in Naples, with a more extensive network of branches and leaves, and with delicate red flowers blossoming towards the top of its stem.

The botanical illustrations that accompany the version of De materia medica in the New York Dioskourides also fit into this typological picture. Of the 443 species illustrated in this book, 282 are also illustrated in both the Vienna and Naples manuscripts, seven are found only in the Vienna and New York manuscripts, forty-five are found only in the Naples and New York manuscripts, and ninety-nine are exclusive to the New York manuscript alone. Whenever the same species is illustrated both in the New York codex and in one or both of the earlier codices, the illustrations are usually sufficiently similar to suggest that they are

\footnotetext{
${ }^{26}$ These are the illustrations of the 'male' and 'female' mandrake. The missing folios containing these illustrations were replaced in the thirteenth or fourteenth century by folios with rough illustrations of the mandrake and text written in a different script (fols. 287-289). Conversely, the thirty-two botanical illustrations that are found in the Vienna Dioskourides but not in the Naples codex can all be explained by reference to the missing folios in the latter manuscript: so Lilla 1992: 60-8.

${ }^{27}$ Contra Singer 1927: 20, suggesting that the Naples codex was copied directly from its counterpart in Vienna.

${ }^{28}$ For this figure, see Orofino 1992: 104-5.
} 
versions of the same original design (fig. 1). The illustrations that are exclusive to the New York Dioskourides, for their part, have been described as 'rudimentary', ${ }^{29}$ and tend not to correspond very closely with the chapters of Dioskourides' treatise that they purport to illustrate.

The observation that some botanical illustrations are confined to the manuscripts in New York and Vienna while others are confined to those in New York and Naples is significant, since this duality precludes the possibility that the illustrations of the New York codex were modelled exclusively on those of either of these earlier codices. Confirmation of this fact is supplied by the 282 illustrations in the New York Dioskourides that have parallels in both the Vienna and Naples codices, since some are closer to their counterparts in the Vienna codex than those in the Naples codex, others are closer to their counterparts in the Naples codex than those in the Vienna codex, while in some cases it is difficult to tell. ${ }^{30} \mathrm{~A}$ possible explanation for this nexus of connections is that the artists of the New York Dioskourides had access to both the Vienna and Naples codices when executing the manuscript. ${ }^{31}$ But this contingency seems speculative - even unlikely - when we consider the lapse in time between the production of the Vienna and Naples codices and the New York codex, as well as the idiosyncrasies of the New York manuscript in terms of its formatting and contents, which will be enumerated in detail in the next section. ${ }^{32}$

In short, then, the typological differences between the three codices demonstrate that the botanical illustrations of the Naples and New York manuscripts were not copied directly and exclusively from those of the Vienna exemplar. Rather, the 'genetic connections' between the illustrations of the three codices can only be explained with reference to a visual source (or sources) outside the surviving manuscripts themselves.

\section{THE AUTHORITATIVE CODEX THEORY}

It is in this context that we should consider the alternative theory that the illustrations of all three codices were modelled on those of a now lost 'authoritative codex' containing an

\footnotetext{
${ }^{29}$ van Buren 1973: 68.

30 So Janick, Whipkey and Stolarcyzk 2013: 3-4.

31 Suggested by Janick, Whipkey and Stolarcyzk 2013: 3-5; cf. Collins 2000: 64-5.

32 So already Touwaide 2006: 41: 'the New York manuscript does not necessarily depend directly on the Vienna Dioscorides'.
} 
alphabetical version of De materia medica accompanied by a comprehensive set of botanical illustrations. ${ }^{33}$

A recent instantiation of this theory holds that an authoritative codex of this kind could have been commissioned for Theodosius II (A.D. 402-450), ${ }^{34}$ the great-grandfather of Anicia Juliana on her mother's side. ${ }^{35}$ This view stems from the testimony of Sozomen, a Christian historian of the fifth century, who states explicitly in the preface to his Ecclesiastical History that Theodosius II enjoyed studying late into the night, and that he was interested in the properties of roots and their cures. ${ }^{36}$ In truth, however, the intersection between Theodosius' intellectual interests and the contents of our surviving manuscripts is not enough to suggest that this emperor owned a codex that served as a comprehensive archetype. In the absence of any direct evidence, the theory remains entirely speculative.

Several other considerations suggest that the underlying idea of an authoritative codex should be questioned. Particularly revealing are the different ways in which De materia medica is formatted in each of our surviving manuscripts. In the Vienna Dioskourides, the botanical illustrations each occupied a full-page, with the accompanying text situated on the adjacent folio (fig. 4); in the Naples Dioskourides, the illustrations were usually arranged two or three to a page, with the accompanying text written in a column of equivalent width situated immediately beneath (fig. 5); and in the New York Dioskourides, the illustrations were painted into gaps in the text left by the scribe (fig. 6). In the Naples and New York manuscripts, the smaller image formats led to illustrations being simplified or truncated in order to fit the available space, sometimes resulting in a less naturalistic overall appearance.

${ }^{33}$ For the notion of an authoritative codex, see e.g. von Premerstein 1906: 101-10; Mantuani 1906: 276; Singer 1927: 19-29; Buberl 1936: 114-21; id. 1937: 32-3; Weitzmann 1947: 136; Gerstinger 1970: 8-9; Riddle 1985: 208-12, 216; Cavallo 1992: 10; Lilla 1992: 51; Orofino 1992: 100; Lazaris 2017: 98.

${ }^{34}$ For this possibility, see Collins 2000: 45-6; Cruse 2007: 154; J. C. Anderson 2009: 35; Janick, Whipkey and Stolarcyzk 2013: 3, 6.

${ }^{35}$ Anicia Juliana was aware of this familial connection, judging by the inscribed epigram that decorated the Church of St. Polyeuktos in Constantinople, a building that she restored in $c$. 524-527. This inscription is recorded in the Palatine Anthology: see Anth. Gr., I 10, and, for commentary, Whitby 2006. For the excavated remains of the Church of St. Polyeuktos itself, see Mango and Ševčenko 1961: 243-7; Harrison 1989.

${ }^{36}$ Sozomen, Historia ecclesiastica, preface. 
There are also several instances where the illustrations of the Naples and New York codices constitute 'mirror images' of their counterparts in Vienna. ${ }^{37}$ But quite apart from impacting upon the iconography of the illustrations in this manner, the differences in formatting leave us with a fundamental question. If the manuscripts were all modelled on (or descended from) a single, illustrated version of Dioskourides' De materia medica carried in an authoritative codex, why did their designers all interpret and reproduce this model in such markedly different ways?

Further problems are encountered when we consider the contents of the manuscripts, since there are significant differences between the Vienna and Naples codices in terms of the ordering of the individual chapters of the treatise. A good example is provided by the pair of

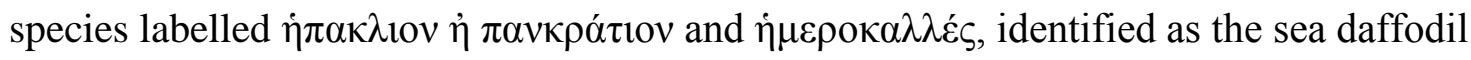
(Pancratium maritimum) and the Martogon lily (Lilium martagon L.) respectively, which were depicted on folios $127^{\mathrm{r}}$ and $133^{\mathrm{r}}$ of the Vienna codex, but which were painted side-byside on folio 79 of the Naples codex. Similarly instructive are the species known as $\Delta \varepsilon \lambda$ qíviov and $\Delta \varepsilon \lambda$ píviov $\dot{\varepsilon} \tau \dot{\rho} \rho o v$, possibly two variants of pellitory (Anthemis pyrethrum L.), which were originally separated by several folios in the Vienna manuscript, ${ }^{38}$ but which were later juxtaposed on folio 61 of the Naples manuscript. Such discrepancies have important implications for the authoritative codex theory, since they require us to believe that the designer(s) of at least one of these manuscripts decided to adjust the order of chapters transmitted by this postulated model.

The theory becomes still more difficult to substantiate when we consider those instances in which a chapter of Dioskourides' text was accompanied by different illustrations in two or more of the surviving codices. The clearest example is supplied by the chapter

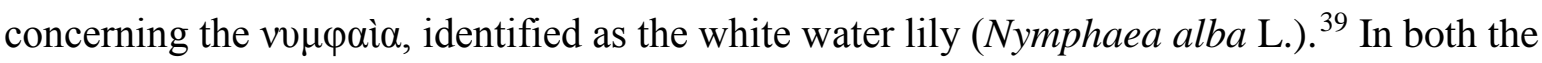
Naples and New York manuscripts, this passage is accompanied by illustrations that conform to Dioskourides' description of the plant, with large heart-shaped leaves and delicate white flowers sprouting from its central stem. In the Vienna manuscript, however, the illustration accompanying the same chapter bears no resemblance to the white water lily itself, but

\footnotetext{
${ }^{37}$ Mirror images: Orofino 1992: 103; Janick and Stolarcyzk 2012: 15.

38 The two examples in the Vienna Dioskourides were originally positioned on fol. 96 and on the folio following fol. 101 (now missing): see Gerstinger 1970: 14.

${ }^{39}$ Dioskourides, De materia medica III, 132.
} 
instead looks like a young fern (fig. 7). ${ }^{40}$ It is clear that this combination of text and image occurred in error, but it is difficult to believe that the designer(s) of the manuscript would have made this mistake if they were working from an authoritative codex in which the correct illustration of the white water lily was obviously available and already associated with corresponding chapter of the treatise. There are also other cases in which the illustrations accompanying the same chapter of text in the Vienna and Naples codices are so far apart that they may represent different species. The illustrations accompanying the chapter concerning the $\beta$ ov́ $\gamma \lambda \omega \sigma \sigma o v$, the Italian bugloss (Anchusa italic Retz), for example, are entirely different in terms of their leaf size, leaf shape, stem prickles, and flowers.

The differences between the Vienna and Naples codices, then, in terms of their formatting, ordering and contents are difficult to reconcile with the notion that the close iconographic correspondences between their illustrations should be attributed to a shared descent from a now lost authoritative codex. ${ }^{41}$ The most we can say is that a common repertoire of botanical illustrations was formulated prior to the production of the Vienna Dioskourides in 512, and that the three manuscripts considered here reproduced overlapping elements of this repertoire during the centuries that followed. These conclusions are important, since they re-open a series of fundamental questions concerning the pre-existing repertoire, notably when its illustrations were formulated, and how these illustrations were transmitted and reproduced during antiquity. In the following sections, these issues will be examined in detail.

\section{DATING THE ILLUSTRATIONS OF THE REPERTOIRE}

It will first be useful to consider the date at which the illustrations of the repertoire were originally conceived. This is a difficult task, since any chronological assessment necessarily depends on a subjective analysis of the style of the illustrations, and of where they fit within

\footnotetext{
${ }^{40}$ Collins 2000: 56.

${ }^{41}$ The extent of the differences between the manuscripts - and the difficulties that they pose for the authoritative codex theory - have been commented on already by Orofino 1992: 101: 'Differences in the distribution of decorative elements indicate that these two manuscripts do not share the same relationship to the original model.' Note also that there are textual differences between the Vienna and Naples manuscripts, which are mentioned briefly by
} Riddle 1985: 191. 
the longue durée of botanical representation in two-dimensional artistic media during antiquity. A further complication is posed by the fact that the illustrations of the Vienna Dioskourides - and so the repertoire - exhibit considerable variety in terms of their style and their fidelity to real life specimens. ${ }^{42}$ A good example of an illustration lying at the more

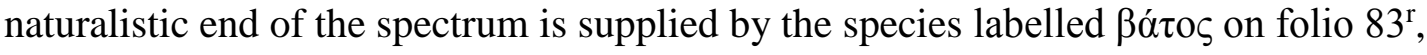
identified as a blackberry bramble (Rubus ulmifolius), which stands out by virtue its refined three-dimensionality and its precisely rendered shapes, colours and contours (fig. 4).

Previous studies have suggested that the most naturalistic illustrations of the Vienna Dioskourides were modelled on classical archetypes, ${ }^{43}$ thanks largely to a perception that they exhibit a level of three-dimensionality and verisimilitude alien to late antique and early Byzantine art. ${ }^{44}$ This viewpoint is too simplistic, since there are other late antique and early Byzantine works of art that incorporate representations of plants and animals depicted with comparable naturalism. A famous example is supplied by the mosaic from the Great Palace at Constantinople, which depicts (among other things) a selection of animals and a series of bucolic scenes against a plain white background, all surrounded by a sumptuous acanthus scroll border. ${ }^{45}$ Clearly this naturalistic mode of representation remained available to patrons who wanted it, and who were prepared to pay a premium for "a somewhat isolated work of art” of this kind. ${ }^{46}$

Still, we cannot deny that a large proportion of the plants and trees depicted in late antique and early Byzantine works of art seem schematic and two-dimensional when compared to the best illustrations of the Vienna Dioskourides. We might compare, for

\footnotetext{
${ }^{42}$ For this variety see Mantuani 1906: 226-9; Singer 1927: 6-7, 24; Buberl 1936: 121; id. 1937: 31; Gerstinger 1970: 8-9; Grape-Albers 1977: 7-21; Orofino 1992: 100-1; Collins 2000: 47-50; Lazaris 2017: 96.

${ }^{43}$ Classical archetypes theory: e.g. von Premerstein 1906: 110-17; Singer 1927: 24; Buberl 1936: 135-6; id. 1937: 33-6; Gerstinger 1970: 7-9; Grape-Albers 1977: 7-10; Cruse 2007:
} 154.

${ }^{44}$ A view summarised neatly by F. J. Anderson 1977: 10: 'the plants are depicted with a greater degree of skill than was evident elsewhere in the Byzantine art of that era, which was very little concerned with subjects of nature, preferring theological and hieratic themes.' ${ }^{45}$ Great Palace mosaic: e.g. Dunbabin 1999: 232-5; Jobst 2005; Parrish 2005, all with further references.

${ }^{46}$ Quotation: Parrish 2005: 1103. 
example, those church mosaics that incorporate representations of symmetrically-disposed flowers, trees and shrubs, including: the apse mosaic of the fifth-century Basilica of St. Apollinare at Classe in Ravenna; ${ }^{47}$ the apse mosaic of the Basilica of San Vitale in Ravenna; ${ }^{48}$ and the narthex mosaic of the Great Basilica in Herakleia Lynkestis in Macedonia (fig. 8). ${ }^{49}$ The fundamental differences in style and approach lend support to the theory that the finest illustrations of the repertoire were modelled on 'classical' archetypes produced in the hellenistic and/or early imperial periods, rather than being conceived for the first time during Late Antiquity. ${ }^{50}$

Further support for this notion of 'classical' origins is supplied by a series of specific iconographic correspondences between the finest botanical illustrations of the Dioskourides codices and representations of the same species in large-scale works of art - particularly wall paintings - surviving from late hellenistic and early imperial times. Previous studies have sometimes alluded to these similarities in very general terms, without adducing any specific points of contact. ${ }^{51}$ Here it will be useful to present a handful of more precise correspondences, which help to add some structure to the theory of classical origins:

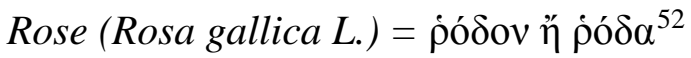

The Vienna Dioskourides contains a full-page illustration of a red rose on folio $282^{\mathrm{r}}$. Illustrations modelled on the same original design are found on folio 129 of the Naples Dioskourides and folio $142^{\mathrm{v}}$ of the New York Dioskourides. Of the latter pair, the New York illustration seems closer to the specimen in the Vienna codex by virtue of its more refined morphology and colouration.

The Vienna illustration depicts a flowering rose bush with a prickly stem and pinnate leaves. Emanating from the stem's branches are three closed rosebuds and three blossoming

\footnotetext{
${ }^{47}$ Basilica of St. Apollinare at Classe: Mazzotti 1954.

${ }^{48}$ San Vitale apse mosaic: Deichmann 1976: esp. 165-6, 178.

${ }^{49}$ Herakleia Lynkestis narthex mosaic: Kolarik 1980: 465-8; Maguire 1987: 36-40; id. 2012: 106-9
}

${ }^{50}$ For the alternative view that the finest illustrations were conceived during Late Antiquity, see Riddle 1985: 179-91, 215-16; Collins 2000: 38, 50.

${ }^{51}$ See, for example, Riddle 1985: 214-15.

${ }^{52}$ Description of species: Dioskourides, De materia medica I, 99. 
flowers. The central flower is turned to face the viewer, while the flower to the left is turned upwards and the flower to the right is turned away. This illustration can be usefully compared to representations of the same species in the garden paintings that decorated the subterranean garden room of the Villa of Livia at Prima Porta and Rooms 31 and 32 of the House of the Golden Bracelet at Pompeii (Fig. 9). ${ }^{53}$ The specimens in the Villa of Livia are depicted behind a low marble balustrade, and a particularly well-preserved example on the long northern wall has three red flowers configured in a manner vaguely reminiscent of the codex illustration.

Oleander (Nerium oleander L.) = $\operatorname{\rho o\delta } \delta \delta a ́ \varphi v \eta^{54}$

The Vienna Dioskourides contains a full-page illustration of an oleander bush on folio $283^{\mathrm{v}}$. Illustrations modelled on a shared, original design are found on folio 130 of the Naples Dioskourides and folio $143^{\mathrm{r}}$ of the New York Dioskourides. Of the latter pair, the New York illustration again seems closer to its counterpart in Vienna.

The specimen depicted in the Vienna codex has five stems, four of which are disposed roughly symmetrically to either side of a central stem. All five stems carry leathery, lanceolate leaves, but only the central stem culminates in bright red flowers. These red flowers are grouped into three clusters, each carried by a small branch sprouting from the central stem. The flowers themselves seem unnaturalistic, since most are rendered as bellshaped openings, possibly inspired by the central corolla tubes surrounded by petals in real life specimens. Still, one of the flowers in the left-hand cluster is a rudimentary constellation of three such petals. A useful point of comparison is supplied by the oleander bush painted on the exterior of Room 78 of the Villa at Oplontis (Fig. 10). ${ }^{55}$ Here, too, the oleander was conceived as a series of symmetrically disposed stems carrying heavy lanceolate leaves, and the bright red flowers were grouped into neat clusters in a roughly symmetrical arrangement.

\footnotetext{
53 Prima Porta garden painting: Gabriel 1955; Kellum 1994; Settis 2002. Garden paintings in the House of the Golden Bracelet at Pompeii: Conticello 1991: 19-24; Ciarallo and Capaldo 1992; Jashemski 1993: 348-56; Ciardiello 2006: 187-8. The most recent overview of garden paintings in Rome and the Bay of Naples is Bergmann 2018.

${ }^{54}$ Description of species: Dioskourides, De materia medica IV, 81.

${ }^{55}$ For the botanical paintings of the Villa A ('of Poppaea') at Oplontis, see now Ricciardi 2014.
} 
Chrysanthemum (Chrysanthemum coronarium L.)= $\beta$ ov́ $\varphi \theta \alpha \lambda \mu \mathrm{ov} \mathrm{v}^{56}$

The Vienna Dioskourides contains a full-page illustration of a chrysanthemum on folio $75^{\mathrm{v}}$. Illustrations modelled on the same original design are found on folio 27 of the Naples Dioskourides and folio $16^{\mathrm{v}}$ of the New York Dioskourides. The Vienna codex also contains an illustration of another variant of this species on folio $373^{r}$, which has analogues on folios 167 and $189^{r}$ of the Naples and New York codices respectively.

The illustration on folio $75^{\mathrm{v}}$ of the Vienna codex is a refined representation of the chrysanthemum, incorporating the bi-pinnately lobed leaves characteristic of this species and three yellow flower heads emanating from its stem. These flower heads are shown in a variety of perspectives, the one to the left in three-quarter view, the one in the centre pointing upwards, and the one to the right in reverse three-quarter view. This illustration can also be compared to representations of the same species from the Villa of Livia at Prima Porta and the House of the Golden Bracelet at Pompeii. On the southern wall at the Villa of Livia, for example, we observe a specimen whose flowers are depicted in a comparable array of perspectives.

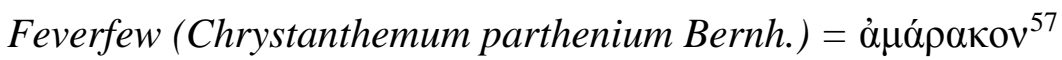

The Vienna Dioskourides contains a full-page illustration of a feverfew plant on folio $31^{\mathrm{v}}$. A less refined representation of the same species can be found on folio 7 of the Naples Dioskourides. The Vienna codex also contains another illustration of the feverfew - or perhaps a closely related species - on folio $193^{\mathrm{r}}$, which is paralleled on folio 170 of the Naples codex.

The specimen depicted on folio $31^{\mathrm{v}}$ of the Vienna manuscript stands out for its sumptuous naturalism. Indeed, the bi-pinnately lobed leaves emanating from the stem are elegantly rendered, and its daisy-like flower heads are shown in a variety of perspectives. Again the illustration can be compared to representations of the same species from the Villa of Livia at Prima Porta and the House of the Golden Bracelet at Pompeii (Fig. 11). A

\footnotetext{
${ }^{56}$ Description of species: Dioskourides, De materia medica III, 139.

${ }^{57}$ Description of species: Dioskourides, De materia medica III, 138.
} 
specimen from the eastern wall of Room 32 of the House of the Golden Bracelet, for example, is depicted with delicate lobed leafs of a similar kind.

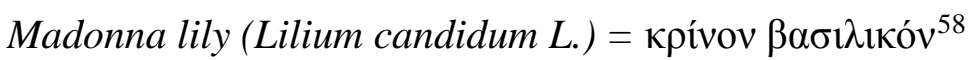

The Vienna Dioskourides contains a full-page illustration of a Madonna lily on folio $176^{\mathrm{v}}$. Illustrations modelled on the same original design are found on folio 82 of the Naples Dioskourides and folio $84^{\mathrm{r}}$ of the New York Dioskourides. In the latter codex there is a second illustration of the species on the same folio that has no clear analogue in the earlier manuscripts.

The unique illustration in the New York codex is of particular interest here. The design is simple, with a leafy stem shooting vertically from a bulb that culminates in a single white flower with a symmetrical arrangement of petals, here pointed upwards. Two smaller buds are disposed symmetrically to either side. This illustration closely resembles a representation of the same species in Room 32 of the House of the Golden Bracelet, which likewise culminates in a white flower pointed vertically, with its petals organised in a symmetrical arrangement (Fig. 12).

Some qualifying comments are required. Firstly, these points of contact are by no means close enough for us to be able to trace direct connections between the representations of particular plants in the wall paintings and the codices, in the sense of both reproducing precisely the same original designs. Rather, the most we can say is that certain botanical species were depicted with the same high level of naturalism in both contexts. Secondly, there are important differences between the plant representations of the wall paintings and the codices in terms of both quantity and contextualisation in space. Indeed, a larger number of botanical species is depicted in the codices than in the wall paintings: something to be expected given the fundamental differences in function and format. The botanical specimens in the wall paintings also differ in the sense that they were carefully integrated into largescale works of art, forming single components of more comprehensive designs.

Even so, these similarities lend a greater sense of precision to the theory that some of the botanical illustrations of the Vienna Dioskourides and its related manuscripts should be traced back to classical archetypes. The very clear correspondences in morphology and

${ }^{58}$ Description of species: Dioskourides, De materia medica III, 102. 
colouration may betray an indirect connection with these earlier representations of the same species, even if the precise nature of this connection remains difficult to pin down.

Additional support for this interpretation is supplied by the illustrations that accompany the subsidiary treatises in the Vienna and New York codices. Particularly instructive are the ornithological illustrations that accompany the paraphrase of Dionysios' Ornithiaka in the Vienna codex, ${ }^{59}$ several of which can be compared to depictions of the same species in hellenistic and early imperial wall paintings and mosaics. ${ }^{60}$ Here it will suffice to mention only the Alexandrine parakeet (Psittacula eupatria) depicted on folio $475^{\mathrm{v}}$ of the Vienna codex, which recalls the famous mosaic emblema depicting this species excavated in Palace V in Pergamon, ${ }^{61}$ as well as a series of later representations surviving from Pompeii and elsewhere; the purple swamp-hen (Porphyrio porphyrio) depicted on folio $480^{\mathrm{v}}$, which can be compared, for instance, to a specimen depicted on the eastern wall of room 32 of the House of the Golden Bracelet at Pompeii; ${ }^{62}$ and the mute swan (Cygnus olor) depicted on folio $482^{\mathrm{v}}$, which resembles very closely the representation of the same species (labelled ' $\alpha i \gamma$ í $\lambda \omega \psi$ ') on the verso of the Artemidorus papyrus. ${ }^{63}$ We might also mention the illustration of a cobra confronting a mongoose that accompanies Euteknios' paraphrase of Nikander's Theriaka in the New York codex (fol. 345), which recalls a zoological topos recorded by ancient writers including Aristotle and Pliny the Elder. ${ }^{64}$ This miniature can be compared to three representations of the same subject surviving from hellenistic and imperial Italy (fig. 13): a vignette in the late-second-century-B.C. Nile Mosaic at Praeneste; ${ }^{65}$ a scene

${ }^{59}$ For these ornithological illustrations see Mantuani 1906: 230-4; Buberl 1936: 134-5; id. 1937: 56-62; Gerstinger 1970: 45-9; Weitzmann 1947: 94-5; id. 1977: 71; Kádár 1978: 7790; Tammisto 1997: 189-90; Brubaker 2002: 201; Roby 2017: 518-9.

60 These artistic media were closely related in the sense that they sometimes reproduced precisely the same pictorial image schemes, no doubt using models of a very similar kind. ${ }^{61}$ Pergamene emblema: Kawerau and Wiegand 1930: 61-3; Salzmann 1995: 108-10; Andreae 2003: 42-4.

${ }^{62}$ House of the Golden Bracelet painting: Ciarallo 1991: 25-31; Conticello 1991; Ciarallo and Capaldo 1992; Jashemski 1993: 348-56 cat. 60; Ciardiello 2006: 187-8.

${ }^{63}$ Artemidorus papyrus swan: Gallazzi, Kramer and Settis 2008: 361-3.

${ }^{64}$ Arist., HA 612a; Plin., HN VIII 88. For this topos in visual culture more broadly, see e.g. see Trinquier 2009: 363; Mielsch 1986: 752; id. 2005: 66-71.

65 Section 21 of the Nile Mosaic: Meyboom 1995: 27. 
in the late-second-century B.C. Nilotic mosaic decorating the threshold of the exedra containing the Alexander Mosaic in the House of the Faun at Pompeii; ${ }^{66}$ and a pair of painted panels that decorated the socle of the rear wall of the Ekklesiasterion of the Temple of Isis at Pompeii. ${ }^{67}$

\section{THE TRANSMISSION OF THE REPERTOIRE}

The hypothesis presented here, then, is that some of the best botanical illustrations of the repertoire depended on classical archetypes. It is important to consider how these 'classical' illustrations might have been preserved and transmitted all the way from the hellenistic and/or imperial period(s) until the production of the Vienna Dioskourides in the early sixth century - and beyond.

This question bears on one of the most controversial issues in the study of ancient art: how best to account for the transmission of detailed images over long geographical distances and/or extended chronological periods. Studies attempting to explain this phenomenon have traditionally drawn on two theoretical possibilities. ${ }^{68}$ The first is that artists were taught how to depict particular subjects in a workshop environment, and that they were subsequently able to reproduce these designs from memory alone. ${ }^{69}$ The second possibility is that artists instead used artistic intermediaries of some description: that is, images carried on transportable media that could be copied and consulted when executing particular designs. ${ }^{70}$ These possibilities are not mutually exclusive, and a large proportion of artistic production in antiquity can be accounted for by some combination of the two. In the particular case of the botanical repertoire, however, the enormous number of illustrations, their intricate, repeated details, and their prolonged period of circulation suggest that at least some were transmitted using artistic intermediaries rather than through workshop tradition and artistic memory alone.

\footnotetext{
${ }^{66}$ Nilotic threshold mosaic: Andreae 2003: 111-25.

${ }^{67}$ Ekklesiasterion paintings: Elia 1942; Moormann 2011: 149-68.

${ }^{68}$ For a balanced synopsis of both possibilities, see Dunbabin 1999: 300-3.

${ }^{69}$ For this approach, see e.g. Bruneau 1984; id. 2001.

${ }^{70}$ Recent proponents of this approach include Donderer 2005; id. 2005/6; Schmidt-Colinet 2009; id. 2016; Clarke 2010.
} 
We are then faced with the question of the material format of these intermediaries. It is inconceivable that the 'classical' illustrations of the repertoire were originally executed and/or transmitted on parchment codices, since the parchment codex was not invented until at least the high imperial period, and did not come into widespread use until considerably later. ${ }^{71}$ In other words, there is a significant chronological gap separating our postulated 'classical' archetypes from the widespread adoption of the parchment codex, and this gap speaks against the possibility that the repertoire was transmitted using this medium.

Previous studies have therefore favoured the view that the illustrations of the repertoire originated in the context of illustrated herbal treatises executed on papyrus. This theory stems from the observation that many of the earlier chapters of De materia medica in the Vienna codex, from folios 12 to $42^{r}$ and 70 to 94 , are supplemented by extracts from the pharmacological treatises written by Galen of Pergamon and by Krateuas the rhizotomist ('root-cutter'), an hellenistic herbalist who served as the personal physician of Mithridates VI Eupator of Pontos (120-63 B.C.). ${ }^{72}$ Given its hellenistic date, there can be no doubt that Krateuas' treatise was originally executed in the papyrus roll format. We also know that it was illustrated thanks to an important passage of Pliny the Elder's Natural History:

Krateuas, Dionysios and Metrodorus adopted a most attractive method, though one that makes clear little else except the difficulty of employing it. For they painted likenesses of plants and then wrote under them their properties. But not only is a picture misleading when the colours are so many, particularly as the aim is to copy Nature, but besides this, much imperfection arises from the manifold hazards in the accuracy of copyists. In addition, it is not enough for each plant to be painted at one period only of its life, since it alters its appearance with the fourfold changes of the year. For this reason the other writers have given verbal accounts only: some have not even given the shape of the plants, and for the most part have been content with bare names, since they thought it sufficient to point out the properties and nature of a plant to those willing to look at it. ${ }^{73}$

\footnotetext{
${ }^{71}$ Invention of parchment codex: Turner 1977; Roberts and Skeat 1987; Kotzabassi 2017.

${ }^{72}$ On Krateuas, see Keyser and Irby-Massie 2008: 491 s.v. 'Krateuas (100- 60 BCE)’ and Scarborough 2012, both with further references.

${ }^{73}$ Plin., HN XXV, 4-5.
} 
Viewed together, then, this passage and the Krateuas quotations in the Vienna codex have been taken as evidence that at least some of the repertoire illustrations were transmitted by illustrated papyrus roll herbals composed by writers like Krateuas, as well as by Dioskourides himself. $^{74}$

There are however serious difficulties with this theory. Firstly, we have noted already that it is far from certain that Dioskourides' original papyrus-roll De materia medica was illustrated. Secondly, Pliny explicitly states that the botanical illustrations that accompanied the work of Krateuas and his contemporaries often failed to achieve a truly naturalistic effect, an assessment that hardly holds true for the finest illustrations of the repertoire. A degree of caution is necessary here, since the inability of art to imitate nature accurately constitutes a recurring topos in the Natural History, ${ }^{75}$ suggesting that Pliny's assessment was influenced by rhetorical considerations as opposed to constituting a purely objective appreciation of the quality of botanical illustrations that he discusses. Compare, for example, the same author's well-known chapters on portraiture, in which he laments the decline of this art form in his own time in a manner that seems completely incongruous with the virtuoso portraits surviving from the late-Julio Claudian and Flavian periods. ${ }^{76}$ Still, Pliny’s comments on the illustrated treatises of Krateuas and his contemporaries remain difficult to reconcile with the view that the finest illustrations of the repertoire originated in the context of the illustrated papyrus roll herbal.

Even stronger objections to this theory can be founded on material considerations, since there are several inherent characteristics of the papyrus roll format that made it poorly suited to carrying large, detailed, polychrome illustrations of the kind preserved in our surviving parchment codices. ${ }^{77}$ Indeed, the rough surface of papyrus meant that it was difficult for artists to execute intricate details when composing illustrations in this format.

\footnotetext{
${ }^{74}$ For this interpretation, see e.g. von Premerstein 1906: 110-17; Singer 1927: 24; Buberl 1936: 135-6; id. 1937: 33-6; Gerstinger 1970: 7-9; Grape-Albers 1977: 7-10; Horsfall 1983: 204.

${ }^{75}$ For this topos see e.g. Plin., HN VII, 8; XXI, 2. Recent commentary: Carey 2003: 133-7. ${ }^{76}$ Plin., HN XXXV. Commentary: Isager 1991: 115-23; Carey 2003: 141-56.

${ }^{77}$ Pointed out already by Riddle 1985: 190-1: 'it is almost inconceivable for an original papyrus painting to have closely resembled the Anicia drawings.' cf. Collins 2000: 38.
} 
Moreover, any illustrations executed in thick paint on papyrus would have suffered greatly from the repeated rolling and unrolling of the scroll. ${ }^{78}$

These considerations are well exemplified by two fragmentary illustrated herbal treatises on papyrus, both originally from Egypt. The first, recomposed of twenty fragments found in Tebtunis (Umm el-Baragât) in the Fayyum, can be dated to the second century A.D. on palaeographic grounds, and offers a unique example of an illustrated herbal treatise executed in the papyrus roll format. ${ }^{79}$ From the surviving fragments it is clear that the roll contained descriptions of botanical species arranged in columns beneath their accompanying illustrations. The surviving passages of text pertain to the chondrilla (Chondrilla juncea L.) and false dittany (Ballota acetabulosa L.), and both exhibit certain correspondences with Dioskourides' descriptions of the same species, ${ }^{80}$ perhaps indicating a reliance on common sources. The artistry of the accompanying illustrations, however, falls far short of the illustrations of the Vienna Dioskourides, being described by the original editor as 'crude and unreal' ${ }^{81}$ Equally instructive is a papyrus codex leaf from Antinoöpolis (Sheikh 'Ibada), dated on palaeographic grounds to $c .400$ (fig. 14). ${ }^{82}$ This codex leaf carries painted botanical illustrations on both sides, with each positioned in the space above a short passage of otherwise unknown text. The text and image on Side A pertain to a botanical species known as the sumphuton, which should perhaps be identified as the comfrey (Symphyton officinale L.), while the text and image on Side B pertain to the species known as the phlomos, which should perhaps be identified as a mullein (Verbasum sinuatum L.). While these botanical

${ }^{78}$ See, for example, Weitzmann 1977: 10: 'Flat parchment sheets, not having to be rolled like papyrus, permitted the application of thicker layers of paint. This offered the possibility of copying pictorially those more advanced panel and fresco paintings with which miniature painting soon competed in refinement and coloration. Moreover, the codex page invited the isolation and enlargement of a single scene and thus the imitation of the general effect of an actual panel, fresco or mosaic.’

${ }^{79}$ More fully on this papyrus roll herbal: Johnson 1913: 403-8; Marganne and Istasse 2001: 1; Fausti 2004: 133-6; Marganne 2004: 37-8; Ryholt 2013.

${ }^{80}$ Chondrilla: Dioskourides, De materia medica II, 133. False dittany: Dioskourides, De materia medica III, 32.

81 Johnson 1913: 404.

${ }^{82}$ More fully on this papyrus codex herbal: Marganne and Istasse 2001: 2; Fausti 2004: 13646; Marganne 2004: 38-9; Leith 2006. 
illustrations are more vibrant than their counterparts on the Tebtunis papyrus, they remain schematic in appearance, and do not approach the naturalism of many of the illustrations of the Vienna Dioskourides.

These papyri strongly suggest that the finest botanical illustrations of the repertoire did not depend on earlier illustrations contained in herbal treatises executed on papyrus, and the same conclusion is reached even if the scope of comparison is extended to include the entire corpus of illustrated papyri surviving from antiquity. Simply put, even the best papyrus roll illustrations of the hellenistic and imperial periods fall well short of the artistry of the botanical illustrations of the Vienna Dioskourides. ${ }^{83}$ To take just one example, the muchdiscussed anatomical and zoological illustrations of the Artemidoros Papyrus are comparatively sketchy in appearance, and appear to have been executed by their draughtsmen relatively quickly. ${ }^{84}$

In summary, it seems unlikely that the finest illustrations of the repertoire were first conceived - or transmitted - on either parchment or papyrus. It is therefore worth considering what exactly the botanical illustrations in our surviving codices imply about the artistic intermediaries used to transmit them during antiquity. Firstly, they suggest that these intermediaries carried highly detailed, taxonomically specific illustrations of large numbers of botanical species, which were presumably executed on a scale comparable to - or larger than - that of the full-page illustrations of the Vienna Dioskourides. ${ }^{85}$ Secondly, they suggest that the intermediaries could be reproduced and combined in a flexible manner, accounting for the differences between the Vienna, Naples and New York codices in terms of their formatting, ordering and contents. Thirdly, they suggest that these intermediaries were durable and long-lasting, and that they might sometimes have transmitted botanical designs from the imperial period into Late Antiquity and beyond.

There is, in fact, a final possibility that could account for all three criteria: that detailed illustrations of botanical species were transmitted on whitened wooden boards

83 The standard catalogue of illustrated papyri from antiquity is Horak 1992. More recent contributions to the corpus include: Stauffer 2008; Froschauer 2008; and Whitehouse 2016. ${ }^{84}$ Illustrations of Artemidoros Papyrus: Gallazzi, Kramer and Settis 2008; Elsner 2009; Adornato 2016.

${ }^{85}$ Cf. Collins 2000: 46: 'Their proportions in relation to the codex page give no indication that they have been enlarged, lengthened or widened awkwardly from another format, but instead suggest that they were originally conceived for a support of similar proportions.' 
known as pinakes ( $\pi \dot{v} \alpha \kappa \varepsilon \varsigma)$, leukōmata $(\lambda \varepsilon v \kappa \omega ́ \mu \alpha \tau \alpha)$ or sanides ( $\sigma \alpha v i ́ \delta \varepsilon \varsigma)$. Such wooden boards are known to have carried detailed paintings in antiquity thanks to a selection of epigraphic and literary sources, ${ }^{86}$ notably the inscribed temple inventories from hellenistic Delos. ${ }^{87}$ The perishable nature of these boards means that they have left few traces in the archaeological record, but the Fayyum mummy portraits and other panel paintings surviving from Roman Egypt may offer some indication of their original appearance. ${ }^{88}$ Particularly instructive is a sketched portrait of a woman with a fashionable Antonine hairstyle on a rectangular wooden board $(\mathrm{H}: 36 \mathrm{~cm}, \mathrm{~W}: 24 \mathrm{~cm})$, which also incorporates artist's instructions written in Greek (fig. 15) ${ }^{89}$ According to one view, this board served as the preparatory drawing for a mummy portrait from Tebtunis now in the Phoebe Hearst Museum, ${ }^{90}$ and so may provide some indication of the rôle played by such wooden boards in transmitting detailed iconographic designs during antiquity.

The possibility that the botanical illustrations of the Vienna Dioskourides were transmitted on wooden boards has been suggested already by Stavros Lazaris in an important article published in 2010. ${ }^{91}$ Lazaris pinpointed two features of the Vienna codex that support this hypothesis. Firstly, the full-page illustrations of the codex correspond very neatly with how we envisage wooden boards carrying detailed depictions of individual plants might have appeared. In other words, the formatting of this version of Dioskourides' treatise may have been conditioned by the format of the repertoire. The second observation pertains to one of the prefatory illustrations at the beginning of the codex (fol. $5^{v}$ ) (fig. 16). Here we see Dioskourides, seated to the right, holding a codex and writing a description of the mandrake

${ }^{86}$ For painted images on pinakes, leukomata and sanides during antiquity, see, for example, Dittenberger: 1915-1921: nos. 364 (1. 5), 577 (1. 85), 958 (1. 40) and 1157 (1. 30-35), and Index, s.v. leukoma; Fischer 2003.

${ }^{87}$ Pinakes in Delos temple inventories: Jones 2014.

${ }^{88}$ For an innovative study of 59 panel paintings with pagan subjects from Roman Egypt, see Mathews and Muller 2016 (with a list of the paintings at p. 240). For a useful review see Borg 2018.

${ }^{89}$ For this remarkable board, see e.g. Parlasca 1977: 76-7 no. 432; Borg 1996: 12 n. 52, 50; Walker and Bierbrier 1997: 122-3 cat. 118.

${ }^{90}$ Walker and Bierbrier 1997: 122-3.

${ }^{91}$ Lazaris 2010: esp. 104-8. See also Stückelberger 1994: 13-15, suggesting that Aristotle’s illustrations were carried on leukomata. 
that is being held aloft by a female figure labelled as a personification of Intelligence ( $\dot{\varepsilon} \pi^{i} \operatorname{lol}_{\alpha}$ ) in the centre of the scene. To the left, an unnamed artist is shown painting the mandrake on a large, loose sheet that has been pinned to an easel. ${ }^{92}$ The fact that the designer of this illustration insisted upon the spatial separation of text and image may reveal something about the nature of the archetypes used by the designers of the version of $D e$ materia medica contained within the codex itself.

This hypothesis also accords well with the observations presented so far in this article, since the use of wooden boards could account for the differences between the Vienna, Naples and New York manuscripts in terms of their formatting and contents. That is, codex designers working from an un-illustrated version of Dioskourides' treatise and a series of loose pinakes carrying botanical illustrations might choose to combine and compile these in a variety of ways.

Lazaris’ observations concerning the Vienna Dioskourides contributed to his overarching theory that medical texts and illustrations were sometimes created and circulated independently during antiquity. As we shall see, this theory has important implications for our understanding of how scientific texts were experienced and understood by contemporary readers. But this focus on reader experience did not allow Lazaris to engage with more detailed questions concerning the chronological and cultural origins of the botanical repertoire, or to consider the broader art historical issue of how intricate, large-scale artistic designs were transmitted and reproduced during antiquity. While this art historical issue will be tackled in Section VI, it will first be useful to offer two further observations concerning the origins of the repertoire.

Firstly, we should not necessarily assume that all of the botanical illustrations of the repertoire originated in the same place and at the same time. That this was not the case is suggested by our earlier observation that the illustrations exhibit considerable variety in terms of their naturalism and fidelity to real life specimens. While the finest illustrations probably descended from classical archetypes, it is possible that some of the less refined illustrations were first conceived at different dates and/or in different cultural and artistic milieux. ${ }^{93}$ In this case, the repertoire would have comprised several sets of illustrations that were

\footnotetext{
92 For a convincing rebuttal of the theory that this figure represents Krateuas, see Lazaris 2010: 107 n. 55.

${ }^{93}$ For this possibility, see already e.g. Grape-Albers 1977: 7-21; Riddle 1985: 179-91, 21516; Collins 2000: 46-50.
} 
combined and consolidated sometime before the production of the Vienna Dioskourides in 512.

Secondly, it is far from certain that all of the illustrations were executed directly in conjunction with (or in response to) Dioskourides’ De materia medica. It is equally possible that some of the illustrations were conceived independently of the treatise, and that the combination of text and image occurred at a comparatively late stage. Support for this view is supplied by the observation that the version of De materia medica in the Vienna codex is a compilation of sorts, combining content taken from a variety of independent sources. Some of the chapters were accompanied by quotations lifted from the herbal treatises of Krateuas (late second or early first century B.C.) and Galen (second century A.D.), and all of the chapters were accompanied by lists of plant-names borrowed from the work of Pamphilos, an Alexandrian grammarian of the first century A.D. ${ }^{94}$ Further evidence is supplied by the illustrated paraphrase of Dionysios' Ornithiaka in the same codex, which is a compilation of a comparable nature. Indeed, many of the naturalistic ornithological illustrations that accompany the treatise do not correspond closely with the contents of the text itself, ${ }^{95}$ again suggesting dependence on a variety of sources.

\section{CONCLUSIONS}

There are then good reasons to suppose that the finest botanical illustrations of the repertoire were transmitted on a comparatively large scale, possibly on whitened wooden boards known as pinakes. To conclude, it will be useful to consider the historical and art historical implications of this hypothesis.

The historical implications have been explored already by Lazaris, who argued that scientific texts and images were sometimes created and consulted independently during antiquity. ${ }^{96}$ This possibility accords very well with the scarcity of surviving papyri carrying detailed, large-scale, polychrome illustrations of the kind contained in our late antique and Byzantine illustrated codices. It also makes good sense when we consider the contexts in which scientific texts and images were consulted in the ancient world. In a library setting, for

\footnotetext{
${ }^{94}$ On Pamphilos, see Keyser and Irby-Massie 2008: 606-7 s.v. 'Pamphilos of Alexandria (60$80 \mathrm{CE})$ ', with further references.

${ }^{95}$ Pointed out, for example, by Collins 2000: 39-40.

${ }^{96}$ So, more fully, Lazaris 2010: 104-9; id. 2013.
} 
instance, the separation of texts and images would have permitted scholars to use a single image as a reference point for more than one text, or to compare two or more images when consulting a single treatise. ${ }^{97}$ In a didactic context, meanwhile, students would have benefitted from consulting independent, large-scale images while texts were read aloud by their tutors. It is tempting to suppose that this was the kind of arrangement envisaged by Theophrastus in a passage of his will quoted by Diogenes Laertius in the early third century A.D.:

"From the funds entrusted to Hipparchos I desire the following distributions to be made... the small stoa adjoining the museion should be rebuilt at least

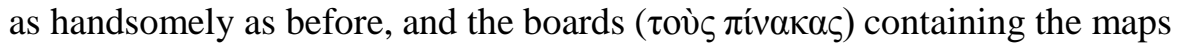

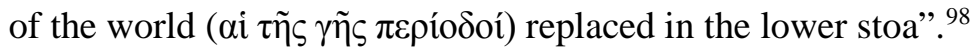

Some scientific fields were better suited to independent images than others. In technical disciplines like mathematics, geometry, architecture, automata and siege-engine construction, illustrations were sometimes crucial for understanding the texts themselves, and so did not lend themselves to spatial separation. Hence Vitruvius, in his De Architectura, eight times refers to illustrations 'at the end of the scroll' (extremo libro or extremo volumine), and twice refers to an illustration 'at the bottom of the page' (ima pagina). ${ }^{99}$ But it is significant that the illustrations that accompanied such works were often simple line drawings executed in ink rather than paint, which could be executed in the papyrus roll format with relative ease. ${ }^{100} \mathrm{In}$ the case of other disciplines - medicine, geography, astronomy, botany and zoology, for instance - illustrations were both less important for understanding the texts themselves, and less suited to the papyrus roll format, increasing the likelihood of texts and images being separated. This view accords well with our surviving corpus of Byzantine illustrated manuscripts concerning these disciplines, several of which incorporate large scale,

\footnotetext{
${ }^{97}$ Recently on libraries in the Byzantine world: Wilson 2008.

${ }^{98}$ Diog. Laert. V 51. Commentary: Stückelberger 1994: 12; id. 2015: 2-3.

${ }^{99}$ References to illustrations 'in extremo libro' or 'in extremo volumine': Vitr. De. Arch. 1.6.12 (referring to two separate diagrams), 3.3.13, 3.4.5, 3.5.8, 5.4.1 and 5.5.6 (both referring to the same diagram), 8.5.3 and 10.6.4. References to illustrations 'in ima pagina': Vitr. De Arch. 9 pref. 5 and 9 pref. 8. Commentary: e.g. Small 2003: 124-5, 210 n. 45. ${ }^{100}$ For this point, see e.g. Spieser 2017: 5.
} 
polychrome, detailed illustrations that might have been descended from earlier, standalone originals. ${ }^{101}$

From an art historical perspective, the view that the illustrations of the repertoire were transmitted using large, detailed models has significant repercussions for our appreciation of how detailed iconographic designs were transmitted and reproduced during antiquity. Indeed, there remains a widespread, problematic assumption that when ancient artists did use preexisting archetypes during the design process, these necessarily took the form of a 'book' of some description. As we have seen, it is very difficult to substantiate the view that the finest botanical illustrations of the Vienna codex were copied from illustrated 'books' made from papyrus, and the same might reasonably be said of detailed designs reproduced in other artistic media, such as mosaics, wall-paintings and relief sculpture.

This 'pattern book problem' is particularly pronounced in those cases where an identical design appears in two works of art separated by large chronological gap and/or geographical distance, and those cases where an extant work of art clearly constitutes a later replica or version of a famous lost original. Here it will be useful to mention a pair of wellknown examples belonging to the latter category: the Alexander Mosaic laid in the House of the Faun at Pompeii, which is demonstrably a replica of a famous royal battle painting of the later fourth century B.C; ${ }^{102}$ and the ethnos reliefs of the North Building of the Sebasteion at Aphrodisias, which were surely modelled on a pre-existing set of depictions of personified conquered territories in Rome itself. ${ }^{103}$ To my mind, it is difficult to envisage how the iconography of such compositions could have been transmitted and reproduced using 'pattern books' in the papyrus roll format. The notion that designs were instead transmitted on a larger scale and in greater detail, perhaps on whitened wooden boards, offers an attractive alternative possibility that deserves further consideration.

${ }^{101}$ Good examples include Vatican City, Biblioteca Apostolica Vaticana, Vat. gr. 1291, a ninth-century manuscript incorporating several full-page astrological illustrations (for which see Spatharakis 1978; Stückelberger 1994: 36) and Biblioteca Laurenziana Medicea: Laur. Plut. 74.7, a late-ninth- or tenth-century-A.D. manuscript containing a version of Apollonios of Kition's treatise On Joints accompanied by twenty-nine full-page illustrations depicting manoeuvres for re-setting dislocated limbs (for which see Stückelberger 1994: 88-90).

102 Alexander Mosaic: Cohen 1997.

103 So, more fully, Smith 2013: 110-21. 


\section{BIBLIOGRAPHY}

Facsimiles of the Naples and New York codices are available online, at:

https://www.wdl.org/en/item/10690/view/1/1/ (Naples)

http://ica.themorgan.org/manuscript/thumbs/143825 (New York)

Adornato, G. (ed.) 2016: Intorno al Papiro di Artemidoro III. I disegni. Atti del Convegno internazionale del 4 febbraio 2011 presso il Gabinetto Disegni e Stampe degli Uffizi, Firenze, Pisa

Anderson, F. J. 1977: An Illustrated History of the Herbals, New York

Anderson, J. C. 2009: 'The Vienna Dioscorides and portraits that tell stories’, in J.

Alchermes, H. Evans and T. K. Thomas (eds), Anathemata eortika: Studies in Honor of Thomas F. Mathews, Mainz, 32-9.

Andreae, B. 2003: Antike Bildmosaiken, Mainz am Rhein

Anichini, M. 1956: 'Il Dioscoride di Napoli', Atti dell'Accademia nazionale dei Lincei: Rendiconti della Classe di Scienze morali, storiche e filologiche ser. 8 vol. 11, 77-104

Beck, L. Y. 2011: Dioscorides Pedanius of Anazarbus, De materia medica ( $\left.2^{\text {nd }} \mathrm{edn}\right)$, Hildesheim NY

Bergmann, B. 2018: 'Frescoes in Roman gardens’, in W. F. Jashemski, K. L. Gleason, K. J. Hartswick and A.-A. Malek (eds), Gardens of the Roman Empire, Cambridge, 278316

Bertelli, C. 1992: ‘A proposal concerning the client of the Neapolitan Dioscurides', in Bertelli, Lilla and Orofino 1992, 125-31

Bertelli, C. 1998: 'The production and distribution of books in Late Antiquity', in R. Hodges and W. Bowden (eds), The Sixth Century: Production, Distribution, and Demand, Leiden, 41-60

Bertelli, C., Lilla, S., and Orofino, G. 1992: Dioscurides Neapolitanus: Biblioteca Nazionale di Napoli, Codex ex Vindobonensis Graecus I. Commentarium, Rome

Bianchi Bandinelli, R. 1959: 'Il Dioscoride neapolitano’, La parola del passato 11, 48-51

Blunt, W., and Rafael, S. 1994: The Illustrated Herbal ( $2^{\text {nd }}$ edn), London

Bonner, C. 1922: ‘A papyrus of Dioscorides in the University of Michigan collection’, Transactions and Proceedings of the American Philological Association 52, 142-68

Borg, B. 1996: Mumienporträts: Chronologie und kultureller Kontext, Mainz am Rhein 
Borg, B. 2018: Review of Mathews and Muller 2016, Journal of the American Institute of Conservation 57.1-2, 91-4

Brubaker, L. 2002: 'The Vienna Dioskorides and Anicia Juliana', in A. Littlewood, H. Maguire and J. Wolschke-Bulmahn (eds), Byzantine Garden Culture, Washington D.C., $189-214$

Bruneau, Ph. 1984: 'Les mosaïstes antiques: avaient-ils des cahiers de modèles?', Revue Archéologique 2, 241-72

Bruneau, Ph. 2000: 'Les mosaïstes antiques: avaient-ils des cahiers de modèles? Suite, probablement sans fin.', Ktèma: civilisations de l'Orient, de la Grèce et de Rome antiques 25, 191-7

Buberl, P. 1936: 'Die antiken Grundlager der Miniaturen des Wiener Dioskurideskodex', Jahrbuch des Deutschen Archäologischen Instituts 51, 114-36

Buberl, P. 1937: Die byzantinischen Handschriften 1. Der Wiener Dioskurides und die Wiener Genesis, Leipzig

Capizzi, C. 1968: ‘Anicia Giuliana (462 ca. - 530 ca.): Ricerche sulla famiglia e la sua vita’, Rivista di studi bizantini e neoellenici 5, 191-226

Carey, S. 2003: Pliny's Catalogue of Culture: Art and Empire in the Natural History, Oxford Cavallo, G. 1992: 'Introduction’, in Bertelli, Lilla and Orofino 1992, 9-13

Ciarallo, A. 1991:

Ciarallo, A., and Capaldo, L. 1992: ‘163. Room (oecus) with garden paintings’, in Rediscovering Pompeii, Rome, 227-39

Ciardiello, R. 2006: 'La casa del bracciale d’oro (VI, 17, 42 Ins. Occ.)’, in M. Aoyagi and U. Pappalardo (eds), Pompei (Regiones VI - VII) Insula Occidentalis, Tokyo, 69-125

Clarke, J. R. 2010: 'Model-book, outline-book, figure-book: new observations on the creation of near-exact copies in Romano-Campanian painting', in I. Bragantini (ed.), Atti del $X^{e}$ congresso internazionale: Association Internationale pour la Peinture Murale Antique (AIPMA), vol. I, Naples, 203-14

Cohen, A. 1997: The Alexander Mosaic: Stories of Victory and Defeat, Cambridge

Collins, M. 2000: Medieval Herbals: the Illustrative Traditions, London

Conticello, B. 1991: 'Il giardino dipinto nella casa del bracciale d'oro', in Il giardino dipinto nella casa del bracciale d'oro a Pompei e il suo restauro, Florence, 19-24 
Cronier, M. 2012: 'Un manuscrit méconnu du De materia medica de Dioscoride: New York, Pierpont Morgan Library, M. 652', Revue des Études Grecques, Les Belles Lettres 125.1, 93-138

Cruse, A. 2007: 'Dioscorides of Anazarbus (fl. A.D. 70): from Mithridates to the Middle Ages', in L. Gilmour (ed.), Pagans and Christians from Antiquity to the Middle Ages: Papers in Honour of Martin Henig Presented on the Occasion of his $65^{\text {th }}$ Birthday, Oxford, 151-61

Deichmann, F. W. 1976: Ravenna: Hauptstadt des spätantiken Abendlandes. Kommentar, 2. Teil, Wiesbaden

Diez, E. 1903: 'Die Miniatur des Wiener Dioskurides’, Byzantinische Denkmaler 3, 1-69 Dittenberger, W. 1915-1921: Sylloge inscriptionum graecarum, 4 vols (3rd edn), Leipzig Donderer, M. 2005: 'Und es gab sie doch! Ein neuer Papyrus und das Zeugnis der Mosaiken belegen die Verwendung antiker „Musterbücher“”, Antike Welt 36.2, 59-68

Donderer, M. 2005/6: ‘Antike «Musterbücher» und (k)ein Ende. Ein neuer Papyrus und die Aussage der Mosaiken’, Musiva \& Sectilia 2/3, 81-113

Dunbabin, K. M. D. 1999: Mosaics of the Greek and Roman World, Cambridge

Elia, O. 1942: Monumenti della pittura antica scoperti in Italia. Sezione III, Pompei, fasc. III: Le pitture del tempio di Iside, Rome

Elsner, J. 2009: 'P. Artemid.: the images', in K. Brodersen and J. Elsner (eds), Images and Texts on the Artemidorus Papyrus. Working Papers on P.Artemid. (St John's College Oxford, 2008), Historia Einzelschriften 214, Stuttgart, 35-50

Fausti, D. 2004: 'Erbari illustrati su papiro e tradizione iconografica botanica', in I. Andorlini (ed.), Testi medici su papiro, Firenze, 131-50

Fischer, J. E. 2003: 'Sanides and sanidia', in G. W. Bakewell, and J. P. Sickinger (eds), Gestures: Essays in Ancient History, Literature, and Philosophy Presented to Alan L. Boegehold, Oxford, 237-50

Froschauer, H. 2008: Zeichnungen und Malereien aus den Papyrussammlungen in Berlin und Wien, Berlin.

Gabriel, M. M. 1955: Livia's Garden Room at Prima Porta, New York

Gallazzi, C., Kramer, B., and Settis, S. 2008: Il papiro di Artemidoro (P. Artemid.), Milan Gerstinger, H. 1926: Die griechische Buchmalerei, Vienna

Gerstinger, H. 1970: Dioscurides: Codex Vindobonensis med. gr. I der Österreichischen Nationalbibliothek. Kommentarband zu der Faksimileausgabe, Graz 
Grape-Albers, H. 1977: Spätantike Bilder aus der Welt des Arztes. Medizinische

Bilderhandschriften der Spätantike und ihre mittelalterliche Überlieferung,

Wiesbaden

Hardy, G., and Totelin, L. 2016: Ancient Botany, Abingdon

Harrison, R. M. 1989: A Temple for Byzantium: the Discovery and Excavation of Anicia Juliana's Palace-Church in Istanbul, London

Horak, U. 1992: Illuminierte Papyri, Pergamente und Papiere, Wien

Horsfall, N. 1983: 'The origins of the illustrated book', Aegyptus 63, 199-216

Irwin, M. E. 2016: 'Greek and Roman botany’, in G. L. Irby-Massie (ed.), A Companion to Science, Technology and Medicine in Ancient Greece and Rome, Chichester, 263-80

Isager, J. 1991: Pliny on Art and Society: the Elder Pliny's Chapters on the History of Art, London

Janick, J., and Stolarcyzk, J. 2012: ‘Ancient Greek illustrated Dioscoridean herbals: origins and impact of the Juliana Anicia Codex and the Codex Neopolitanus', Notulae Botanicae Horti Agrobotanici Cluj-Napoca 40.1, 9-17

Janick, J., Whipkey, A. L., and Stolarcyzk, J. 2013: 'Synteny of images in three illustrated Dioscoridean herbals: Juliana Anicia Codex, Codex Neapolitanus, and Morgan 652', Notulae Botanicae Horti Agrobotanici Cluj-Napoca 41.2, 1-7

Jashemski, W. F. 1993: The Gardens of Pompeii, Herculaneum and the Villas Destroyed by Vesuvius, Vol. II: Appendices, New York

Jobst, W. 2005: 'Das Palastmosaik von Konstantinopel: Chronologie und Ikonographie’, in H. Morlier (ed.), La mosaïque gréco-romaine IX, vol. II, Rome, 1083-101

Johnson, J. de M. 1913: ‘A botanical papyrus with illustrations’, Archiv für die Geschichte der Naturwissenschaft und der Technik 4, Leipzig, 403-8

Jones, A. H. M., Martindale, J. R., and Morris, J. 1980: The Prosopography of the Later Roman Empire, Vol. II: A.D. 395-527, Cambridge

Jones, N. B. 2014: ‘Ancient painted panels: terminology and appearance’, Mnemosyne 67.2, 295-304

Kádár, Z. 1978: Survivals of Greek Zoological Illuminations in Byzantine Manuscripts, Budapest

Kalavrezou, I., and Tomaselli, C. 2017: 'The study of Byzantine manuscripts since Kurt Weitzmann: art historical methods and approaches', in Tsamakda 2017, 23-34 Kawerau, G., and Wiegand, Th. 1930: Altertümer von Pergamon V1. Die Paläste der Hochburg, Berlin 
Kellum, B. A. 1994: 'The construction of landscape in Augustan Rome: the garden room at the villa ad Gallinas', The Art Bulletin 76.2, 211-24

Keyser, P. T., and Irby-Massie, G. L. (eds) 2008: The Encyclopedia of Ancient Natural Scientists: the Greek Tradition and its Many Heirs, London

Killerich, B. 2001: 'The image of Anicia Juliana in the Vienna Dioscurides: flattery or appropriation of imperial imagery', Symbolae Osloenses 76.1, 169-90

Kolarik, R. E. 1984: 'The floor mosaics of eastern Illyricum: the northern regions', in Actes du $X^{e}$ congres international d'archéologie chrétienne, Thessalonique 28 septembre4 octobre 1980, vol. I, Rome, 445-79

Kotzabassi, S. 2017: ‘Codicology and palaeography’, in Tsamakda 2017, 35-53.

Lazaris, S. 2010: 'L’illustration des disciplines médicales dans l’antiquité: hypothèses, enjeux, nouvelles interprétations’, in M. Bernabo (ed.), La collezione di testi chirurgici di Niceta: Firenze, Biblioteca medicea laurenziana, Plut. 74.7: tradizione medica classica a Bisanzio, Rome, 99-109

Lazaris, S. 2012: ‘Dell’ugna un leone: le détail comme paradigme épistémologique en sciences de l'Antiquité', Ktèma: civilisations de l'Orient, de la Grèce et de Rome antiques 37, 255-66

Lazaris, S. 2013: 'L’image paradigmatique: des Schémas anatomiques d’Aristote au De materia medica de Dioscuride’, Pallas 93, 131-64

Lazaris, S. 2017: 'Scientific, medical and technical manuscripts', in Tsamakda 2017, 55-113

Leith, D. 2006: 'The Antinoopolis illustrated herbal (PJohnson + PAntin, 3.214 - MP3 2095), Zeitschrift für Papyrologie und Epigraphik 156, 141-56

Lemerle, P. 1986: Byzantine Humanism, Canberra

Lilla, S. 1992: 'A study of the manuscript', in Bertelli, Lilla and Orofino 1992, 49-80

Lowden, J. 2002: “The transmission of "visual knowledge” in Byzantium through illuminated manuscripts: approaches and conjectures', in C. Holmes (ed.), Literacy, Education and Manuscript Transmission in Byzantium and Beyond, Leiden, 59-79

Lowden, J. 2008: ‘Book Production’, in E. Jeffreys, J. F Haldon, and R. Cormack (eds), The Oxford Handbook of Byzantine Studies, Oxford, 462-72

Maguire, H. 1987: Earth and Ocean: the Terrestrial World in Byzantine Art, University Park Maguire, H. 2012: Nectar \& Illusion: Nature in Byzantine Art and Literature, Oxford Mango, C., and Sevcenko, I. 1961: 'Remains of the church of St. Polyeuktos at Constantinople', Dumbarton Oaks Papers 15, 243-7 
Mantuani, I. 1906: 'Die Miniaturen im Wiener Kodex Med. graecus I', in A. von Premerstein, C. Wessely and I. Mantuani, Dioscurides. Codex Aniciae Iulianae picturis illustrates, nunc Vindobonensis med. Gr. I, Leiden, 209-84

Marganne, M.-H. 2004: Le livre médical dans le monde gréco-romain, Liege

Marganne, M.-H., and Istasse, N. 2001: 'Livres de médecine illustrés dans l’Égypte grécoromaine', Medicina nei secoli 13, 1-23

Mathews, T. F., and Muller, N. E. 2016: The Dawn of Christian Art in Panel Paintings and Icons, Los Angeles CA

Mazzotti, M. 1954: La basilica di Sant'Apollinare in Classe, Vatican

Meyboom, P. G. P. 1995: The Nile Mosaic of Palestrina: Early Evidence of Egyptian Religion in Italy, Leiden

Mielsch, H. 1986: 'Hellenistische Tieranekdoten in der römischen Kunst', Archäologischer Anzeiger, 747-63

Mielsch, H. 2005: Griechische Tiergeschichten in der antiken Kunst, Mainz am Rhein

Moormann, E. M. 2011: Divine Interiors: Mural Paintings in Greek and Roman Sanctuaries, Amsterdam

Nathan, G. S. 2011: 'The Vienna Dioscorides’ dedicatio to Anicia Juliana: a usurpation of imperial patronage?', in G. S. Nathan, L. Garland, E. Jeffreys and M. Jeffreys (eds), Basileia: Essays on Imperium and Culture in Honour of E. M. and M. J. Jeffreys, Virginia, Queensland

Orofino, G. 1991: ‘Dioskurides war gegen Pflanzenbilder’, Die Waage 30, 144-9

Orofino, G. 1992: ‘The Dioscurides of the Biblioteca Nazionale of Naples: the miniatures', in Bertelli, Lilla and Orofino 1992, 99-113

Parlasca, K. 1977: Repertorio d'arte dell'Egitto greco-romano. Serie B: ritratti di Mummie, vol. II, Palermo

Parrish, D. C. 2005: 'The art-historical context of the Great Palace mosaic at Constantinople', in H. Morlier (ed.), La mosaïque gréco-romaine IX, vol. II, Rome, 1103-17

Ricciardi, M. 2014: 'Between natural history and artistic invention: representation of plants in the paintings of Villa A', in J. R. Clarke and N. K. Muntasser (eds), Oplontis: Villa A (“of Poppaea”) at Torre Annunziata, Italy, Vol.1: the Ancient Setting and Modern Rediscovery, e-Book

Riddle, J. M. 1971: 'Dioscorides', in Dictionary of Scientific Biography, Vol. IV, New York, $119-23$ 
Riddle, J. M. 1984: 'Byzantine commentaries on Dioscorides', Dumbarton Oaks Papers 38, 95-102

Riddle, J. M. 1985: Dioscorides on Pharmacy and Medicine, Austin TX

Roberts, C. H., and Skeat, T. C. 1987: The Birth of the Codex, Oxford

Roby, C. 2017: 'Framing technologies in Hero and Ptolemy', in V. J. Platt and M. Squire (eds), The Frame in Classical Art: a Cultural History, Cambridge, 514-43

Ryholt, K. 2013: 'The illustrated herbal from Tebtunis: new fragments and archaeological context', Zeitschrift für Papyrologie und Epigraphik 187, 233-8

Salzmann, D. 1995: ‘Zu den Mosaiken in den Palästen IV und V von Pergamon’, Studien Zum Antiken Kleinasien III, 101-12

Scarborough, J. 1984: 'Early Byzantine pharmacology’, Dumbarton Oaks Papers 38, 213-32

Scarborough, J. 2011: 'Introduction’, in Beck 2011, xiii-xxi

Scarborough, J. 2012: 'Crateuas', in S. Hornblower, A. Spawforth and E. Eidinow (eds), The Oxford Classical Dictionary (4 ${ }^{\text {th }}$ edn), Oxford

Scarborough, J., and Nutton, V. 1982: ‘The preface of Dioscorides’ Materia medica: introduction, translation and commentary', Transactions and Studies of the College of Physicians at Philadelphia 5.4, Philadelphia, 187-227

Schmidt-Colinet, A. 2009: “'Musterbücher’ statt 'Meisterforschung': Zum Verständnis antiker Werkstattstrukturen und Produktionsprozesse', Journal of Roman Archaeology 22, 787-92.

Schmidt-Colinet, A. 2016, 'The reconstruction and distribution of pattern books in the Roman Empire: some archaeological evidence from Palmyra’, in Adornato 2016, $129-46$

Settis, S. 2002: La pareti ingannevoli. La villa di Livia e la pittura di giardino, Milan

Singer, C. 1927: 'The herbal in antiquity and its transmission into later ages', Journal of Hellenic Studies 47, 1-52

Small, J. P. 2003: The Parallel Worlds of Classical Art and Text, Cambridge.

Smith, R. R. R. 2013: Aphrodisias VI: the Marble Reliefs from the Julio-Claudian Sebasteion, Darmstadt

Spatharakis, I. 1976: The Portrait in Byzantine Illuminated Manuscripts, Leiden

Spatharakis, I. 1978: 'Some observations on the Ptolemy Ms. Vat. gr. 1291: its date and the two initial miniatures', Byzantinische Zeitschrift 71, 41-9

Spieser, J.-M. 2017: 'The use and function of illustrated books in Byzantine Society’, in Tsamakda 2017, 3-22 
Stauffer A. 2008: Antike Musterblätter: Wirkkartons aus dem spätantiken und frühbyzantinischen Ägypten, Wiesbaden

Stearn, W. T. 1954: 'The earliest illustrated herbal, Codex Aniciae Juliannae’, Graphis 54, $322-9$

Stückelberger, A. 1994: Bild und Wort. Das illustrierte Fachbuch in der antiken Naturwissenschaft, Medizin und Technik, Mainz am Rhein

Stückelberger, A. 2015: 'Die Illustration als Verständnischilfe in antiken wissenschaftlichen Texten', Vereinigung der Schweizerischen Hochschuldozierenden Bulletin 3, 2-7

Tammisto, A. 1997: Birds in Mosaics: a Study on the Representation of Birds in Hellenistic and Romano-Campanian Tessellated Mosaics to the Early Augustan Age, Rome

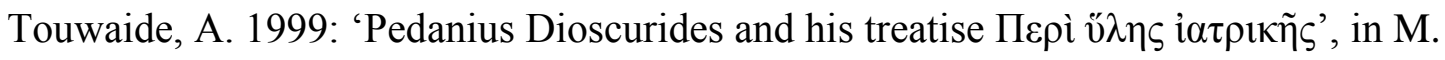
Giancaspro, G. Cavallo and A. Touwaide (eds), Dioscurides De materia medica. Codex Neapolitanus graecus 1 of the National Library of Naples. Facsimile Reproduction of the Manuscript with Introductory Texts, Athens, 37-55

Touwaide, A. 2006: 'Latin crusaders, Byzantine herbals’, in J. A. Givens, K. M. Reeds and A. Touwaide (eds), Visualizing Medieval Medicine and Natural History, 1200-1550, Aldershot, 25-50

Touwaide, A. 2013: 'Illustration, scientific', in R. S. Bagnall, K. Brodersen, C. B. Champion, A. Erskine and S. R. Huebner (eds), The Encyclopaedia of Ancient History, Vol. VI, Oxford, 3404-7

Trinquier, J. 2009: 'L’animal, le roi et le savant: le “Musée” et le développement des savoirs sur l'animal dans d'Alexandrie lagide', in F. Le Blay (ed.), Transmettre les savoirs dans les mondes hellénistique et romain, Rennes, 333-66

Tsamakda, V. (ed.) 2017: A Companion to Byzantine Illustrated Manuscripts, Leiden Turner, E. G. 1977: The Typology of the Early Codex, Philadelphia van Buren, A. 1973: 'De Materia Medica of Dioscurides’, in G. Vikan (ed.), Illuminated Greek Manuscripts from American Collections: an Exhibition in Honor of Kurt Weitzmann, Princeton, 66-9

von Premerstein, A. 1903: ‘Anicia Juliana im Wiener Dioskorides-Kodex’, Jahrbuch der kunsthistorischen Sammlungen des allerhöchsten Kaiserhauses 24, 105-24

von Premerstein, A. 1906: 'De Codicis Dioscuridei Aniciae Iulianae, nunc Vindobonensis Med. Gr. I: Historia, Forma, Argumento’, in A. von Premerstein, C. Wessely and I. Mantuani, De codicis Dioscuridei Aniciae Iulianae, nunc Vindobonensis Med. Gr. I: Historia, Forma, Scriptura, Picturis, Leiden, 3-227 
Walker, S., and Bierbrier M. L. 1997: Ancient Faces: Mummy Portraits from Roman Egypt, London

Walther, I. F., and Wolf, N. 2005: Codices illustres: the World's Most Famous Illuminated Manuscripts, 400 to 1600 ( $2^{\text {nd }}$ edn), Köln

Waring, J. 2010: 'Byzantine book culture', in L. James (ed.), A Companion to Byzantium, London, 275-88

Weitzmann, K. 1947: Illustrations in Roll and Codex: a Study of the Origin and Method of Text Illustration, Princeton

Weitzmann, K. 1959: Ancient Book Illumination, Cambridge MA

Weitzmann, K. 1971: 'The classical heritage in the art of Constantinople', in K. Weitzmann and H. L. Kessler, Studies in Classical and Byzantine Manuscript Illumination, Chicago, $125-50$

Weitzmann, K. 1977: Late Antique and Early Christian Book Illumination, Cambridge MA Wellmann, M. 1903: 'Dioskurides’, in A. F. von Pauly and G. Wissowa (ed.), Paulys RealEncyclopädie der classischen Altertumswissenschaft IV, col. 1136

Wellmann, M. 1906-1914: Pedanii Dioscuridis Anazarbei De materia medica libri quinque, in 3 volumes, Berlin

Whitby, M. 2006: 'The St Polyeuktos epigram (AP 1.10): a literary perspective', in S. F. Johnson (ed.) Greek Literature in Late Antiquity: Dynamism, Didacticism, Classicism, Aldershot, 159-88

Whitehouse, H. 2016: 'Birds, beasts and a unicorn at Oxyrhynchus', in Adornato 2016, 10528

Wilson, N. G. 1967: 'The libraries of the Byzantine world', Greek, Roman, and Byzantine Studies 8, 53-80

Wilson, N. G. 1996: Scholars of Byzantium ( $2^{\text {nd }}$ edn), London

Wilson, N. G. 2008: 'Libraries', in E. Jeffreys, J. F Haldon, and R. Cormack (eds), The Oxford Handbook of Byzantine Studies, Oxford, 820-5.

Windstedt, E. O. 1907: ‘Some Greek and Latin papyri in Aberdeen Museum’, Classical Quarterly 1.4, 257-67 